\title{
Buffering capacity and fecal pH in healthy horses submitted to experimental enteral nutrition
}

\section{Capacidade tamponante e pH fecal de equinos sadios submetidos a teste clínico de nutrição enteral}

\author{
Marina Juliani Baumhak; Lilian Emy dos Santos Michima²; Beatriz Moreira \\ Andrioli3; Roberta Ariboni Brandi'; Rebeca Alves Weigel5; Marcílio Nichi6; \\ Carla Bargi Belli7; Renata Farinelli de Siqueira ${ }^{8 *}$
}

\section{Highlights}

The critical equine patient needs to receive a specific diet for recovery.

High levels of soluble carbohydrates in equine diets can lead to acidosis.

Fecal $\mathrm{pH}$ and buffering capacity are indirect tests useful to detect hindgut changes.

\section{Abstract}

This study set out to determine the impacts of a commercial equine enteral nutrition product on fecal $\mathrm{pH}$, buffering capacity $(\mathrm{BC})$ and physical examination variables. Eight healthy horses were randomly allocated to one of two simultaneous experimental groups in a $4 \times 4$ Latin square design. Horses were submitted to 12 hours of solid fasting, then fed increasing doses of the test product via nasogastric tube, as follows: $0 \%$ (pure water), $50 \%, 75 \%$ and $100 \%$ of the daily recommended dose. Test product doses were diluted in water (1:3) and delivered by bolus feeding. Fecal samples were taken directly from the rectal ampulla prior to (T0) and within 3, 6, 12, 24, 36 and 48 hours of product administration (T3, T6, T12, T24, T36 and T48 respectively). Within 24 to 36 hours of product administration, fecal pH was near $6(p=0.01)$. However, dose variation had no effect on $\mathrm{pH}$. Product dose and sample collection time had a significant impact $(p=$

1 Doctor of Veterinary Medicine, Resident in Equine Internal Medicine and Large Animal Surgery Program, Departamento de Clínica Veterinária, Departamento de Cirurgia Veterinária, Faculdade de Medicina Veterinária e Zootecnia, Universidade de São Paulo, FMVZ/USP, São Paulo, SP, Brazil. E-mail: marinajuba@gmail.com

2 Doctor of Veterinary Medicine, PhD in Veterinary Internal Medicine, Sao Paulo, SP, Brazil. E-mail: lilianemy@gmail.com

3 Doctor of Veterinary Medicine, São Paulo, SP, Brazil. E-mail: beatrizmandrioli@gmail.com

4 Professional Animal Scientist, PhD in Animal Science, Associate Professor, Departamento de Zootecnia, Faculdade de Zootecnia e Engenharia de Alimentos, Universidade de São Paulo, FZEA/USP, Pirassununga, SP, Brazil. E-mail: robertabrandi@usp.br

5 Doctor of Veterinary Medicine, PhD in Veterinary Internal Medicine, Curitiba, PR, Brazil. E-mail: rebec@alumni.usp.br

6 Doctor of Veterinary Medicine, PhD, Adjunct Professor, Departamento de Reprodução Animal, Faculdade de Medicina Veterinária e Zootecnia, Universidade de São Paulo, FMVZ/USP, São Paulo, SP, Brazil. E-mail: mnichi@usp.br

7 Doctor of Veterinary Medicine, PhD, Adjunct Professor, Departamento de Clínica Médica, Faculdade de Medicina Veterinária e Zootecnia, Universidade de São Paulo, FMVZ/USP, São Paulo, SP, Brazil. E-mail: cbbelli@usp.br

8 Doctor of Veterinary Medicine, PhD, Adjunct Professor, Departamento de Clinica de Grandes Animais, Centro de Ciências Rurais, Universidade Federal de Santa Maria, CCR/UFSM, Santa Maria, RS, Brazil. E-mail: refarinelli@gmail.com * Author for correspondence

Received: Mar. 24, 2021 - Approved: Ago. 30, 2021 
0.00) on buffering capacity at $\mathrm{pH}$ 6. The more dramatic drop in $\mathrm{pH}$ occurred within 24 to 36 hours of product administration, except in horses receiving the $0 \%$ dose (water). At $\mathrm{pH} 5$, buffering capacity was affected by dose but not by sample collection time. Soft fecal consistency, increased intestinal motility and fat droplets in fecal samples were noted in most horses. Fecal pH and buffering capacity assessment are indirect tests. Still, results obtained from these tests were deemed useful for detection of intestinal changes, particularly when combined with physical examination. The product had an impact on faecal $\mathrm{pH}$, buffering capacity and intestinal motility, therefore, it is recommended that the formulation be revised.

Key words: Acidosis. Carbohydrates. Colic. Equine. Intestine.

\section{Resumo}

O objetivo desse estudo foi avaliar o desempenho de uma formulação comercial para nutrição enteral em equinos quanto aos aspectos de $\mathrm{pH}$ fecal, capacidade tamponante (CT) nas fezes e exame físico. Para tal, utilizaram-se 8 equinos hígidos, distribuídos aleatoriamente em dois Quadrados Latinos 4 X 4 simultâneos, que permaneceram em jejum alimentar 12 horas antes de receberem via sonda nasogástrica doses crescentes de $0 \%$ (somente água), 50\%, 75\% e 100\% da quantidade total diária recomendada do produto, com a diluição estabelecida de três partes de água para cada parte de produto. Foram colhidas amostras de fezes diretamente da ampola retal antes da administração do produto (T0), 3 (T3), 6 (T6), 12 (T12), 24 (T24), 36 (36) e 48 (T48) horas após. Entre 24 a 36 horas após a administração do produto, o pH fecal estava próximo a $6(p=0,01)$. No entanto, a variação da dose não teve efeito sobre o pH. A dose do produto e o tempo de coleta da amostra tiveram um impacto significativo $(p=0,00)$ na capacidade tamponante das fezes em pH 6. A queda mais dramática no pH ocorreu dentro de 24 a 36 horas da administração do produto, exceto em cavalos que receberam a dose de $0 \%$ (água). Em pH 5, a capacidade tamponante das fezes foi afetada pela dose, mas não pelo tempo de coleta da amostra. Consistência fecal mole, aumento da motilidade intestinal e gotículas de gordura nas amostras fecais foram observados na maioria dos cavalos. A avaliação do pH fecal e da capacidade de tamponante são testes indiretos. Ainda assim, os resultados obtidos com essas análises foram considerados úteis para a detecção de alterações intestinais, principalmente quando combinados com o exame físico. O produto teve impacto no $\mathrm{pH}$ fecal, capacidade tamponante das fezes e motilidade intestinal, portanto, recomenda-se que a formulação seja revisada.

Palavras-chave: Acidose. Carboidratos. Cólica. Equinos. Intestino.

\section{Introduction}

In critical patients, nutrition is an important part of hospital treatment and may play a significant role in recovery from infections, traumatic events and surgical interventions. Delayed introduction of feeding has been associated with energy and protein imbalances, immune function compromise, delayed wound healing and longer in-hospital stay (Stratton-Phelps, 2008). Patients who have been off food for more than 36 hours due to inappetence or treatment requirements, or who already had low body condition score upon hospital admission, require nutritional support. Enteral feeding is more physiological, cheaper and less prone to complications than parenteral feeding and is therefore preferable in patients with a healthy gut (Mechanick \& Brett, 2002; Hardy, 2003). 
Enteral nutrition may be provided in several ways. Concentrates and roughage of choice may be blended and resuspended in water (home-made diet), a mix of highly digestible ingredients may be offered (commercial diet) or elemental diets consisting of amino acids and peptides (Hardy, 2003) fed instead. Regardless of the type of diet selected, feeding must be gradually reintroduced. In horses who have been off food for more than 4 days, food should be reintroduced at $25 \%$ of the estimated daily intake and amounts slowly increased over the course of 2 to 4 days. Horses may not need to receive $100 \%$ of their estimated energy requirements, as many are able to maintain their body weight on $75-80 \%$. However, these animals must be monitored for signs of dietary intolerance, such as bloating, increased intestinal motility, soft feces and abdominal discomfort (Geor, 2000).

Critical patient nutrition is not a consensus in Brazil. Also, related literature is scarce and there are not many affordable options in the market. Therefore, veterinarians must often resort to home-made diets, which do not always meet patient's energy and nutrient requirements.

Physicochemical analysis of feces and indirect, non-invasive tests such as fecal $\mathrm{pH}$ and buffering capacity estimation may help determine the effects of nutrition on equine intestinal function (Zeyner, Geibler, \& Dittrich, 2004; Richards, Hinch, \& Rowe, 2006; Santos et al., 2009).

Buffering capacity is the ability of the large intestine to respond to changes in intestinal pH (Santos et al., 2009), i.e., the ability to neutralize acids in order to prevent acidosis development. Fecal $\mathrm{pH}$ varies according to diet. However, optimal fecal $\mathrm{pH}$ ranges have been described. Studies conducted by Berg, Fu, Porter and Kerley (2005), Williamson, Rogers and Firth (2007) and Brøkner, Austbø, Naesset, Knudsen and Tauson (2012) revealed fecal $\mathrm{pH}$ values of $6.48,6.41$ to 6.46 and 6.53 to 6.59 in control horses kept on a roughageonly diet respectively. In a study investigating fecal $\mathrm{pH}$ in horses with restricted access to pasture for 3, 6, 9 and 24 hours, the longer the restriction, the lower the fecal pH (Glunk, PrattPhillips, \& Siciliano, 2013).

In horses fed starch-rich diets, higher counts of amylolytic lactic acid bacteria and resultant increased levels of $D$ and L-lactic acid isomers drive gut $\mathrm{pH}$ down, particularly in the cecum and the ventral colon (Richards et al., 2006; Julliand \& Grimm, 2017). According to Julliand and Grimm (2017), the inability of cellulolytic bacteria to tolerate such changes in $\mathrm{pH}$ may lead to dysbiosis and ultimately to colic and laminitis, among other conditions. Hence, enteral nutrition must also be balanced in order to preserve intestinal health.

This study was designed to determine the impacts of a commercial equine enteral nutrition product on fecal $\mathrm{pH}$, fecal buffering capacity (BC) and physical examination variables.

\section{Materials and Methods}

This Project was approved by Comitê de Ética no Uso de Animais of Faculdade de Medicina Veterinária e Zootecnia of Universidade de São Paulo, protocol No. 2174300916.

Eight healthy male Arabian horses aged 3 to 4 years and weighing $299.38 \pm 19.6 \mathrm{~kg}$ were used. Horses belonged to Pirassununga campus of Faculdade de Medicina Veterinária 
e Zootecnia of Universidade de São Paulo

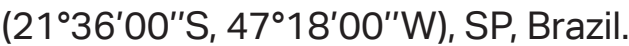

Horses were submitted to a two-week pre-experimental adaptation period, during which time they were fed grass hay to daily energy requirements (2\% of body weight, bwt). Horses were then randomly allocated to one of two simultaneous experimental groups in a $4 \times 4$ Latin square design ( 4 horses x 4 treatments) and treated with increasing doses of a 3:1 water/test product solution as per manufacturer recommendations ( $1 \%$ bwt day or $1000 \mathrm{~g}$ for $100 \mathrm{~kg}$ bwt day), delivered via tube feeding. Single doses corresponding to $0 \%$ (water), $50 \%, 75 \%$ and $100 \%$ of manufacturer recommendations were given by bolus feeding. For the 0\% dose (placebo), the animal would receive the equivalent of the product dose, that is, 3 litres of water.

For feces sample collection purposes, horses were housed in barn stalls and not fed for 12 hours prior to and 12 hours after enteral feeding. Horses were then turned out in a grass paddock and fed hay for three days before the next enteral feeding event.

The product tested in this trial (Equisave $^{\circledR}$, Quimtia) contains whey protein, pre-gelatinized rice, alfalfa hay, micronized soy, soy protein concentrate, organic selenium, calcium iodate, vitamins and amino acids (Table 1) and is sold as a mash product.

Fecal samples were taken directly from the rectal ampulla prior to (TO) and within $3,6,12,24,36$ and 48 hours of test product administration (T3, T6, T12, T24, T36 and T48 respectively). Immediately after collection, $50 \mathrm{~g}$ of feces was mixed with $50 \mathrm{~mL}$ of deionized water and vortexed for 30 seconds using a vortex and then left to equilibrate for 5 minutes. Fecal pH of each sample was measured using a portable phmeter and it was calibrated using a two-point calibration $(\mathrm{pH}$ 4 and 7) to ensure accurate measurements. Buffering capacity (BC) was determined as per Zeyner et al. (2004). A $50 \mathrm{~g}$ aliquot was taken from each fecal sample, mixed with $80 \mathrm{~mL}$ of distilled water, homogenized and filtered. An $80 \mathrm{~mL}$ of this sample was then titrated with $0.25 \mathrm{M}$ acetic acid. The volume of acetic acid required to reduces fecal $\mathrm{pH}$ to $\mathrm{pH}$ of 6 or 5 was defined as buffering capacity in $\mathrm{pH} 6$ (BC6) and 5 (BC5) respectively. The volume of acetic acid employed was expressed as $\mathrm{mmol} \mathrm{L}^{-1}$ of diluted feces using the following equation: $\mathrm{BC}$ $\left(\mathrm{mmol} \mathrm{L}^{-1}\right)=$ Volume $(\mathrm{mL}) \times 3.125$.

\section{Table 1}

\section{Test product guaranteed analysis.}

Moisture (max): $125 \mathrm{~g} \mathrm{~kg}^{-1}$
Crude protein (min): $200 \mathrm{~g} \mathrm{~kg}^{-1}$
Crude fat (min): $90 \mathrm{~g} \mathrm{~kg}^{-1}$
Minerals (max): $60 \mathrm{~g} \mathrm{~kg}^{-1}$
Crude fiber (max): $100 \mathrm{~g} \mathrm{~kg}^{-1}$

Calcium (min - max): 5,000 - 8,000 $\mathrm{mg} \mathrm{kg}^{-1}$ Phosphorus (min): $3,700 \mathrm{mg} \mathrm{kg}^{-1}$

Bacillus licheniformis: $640,000,000$ CFU kg-1

Bacillus subtilis: $640,000,000 \mathrm{CFU} \mathrm{kg}^{-1}$ Crude energy: $4,000 \mathrm{kcal} \mathrm{kg}^{-1}$

Vitamins: A (min) 1,547 IU kg-1; D3 (min) 3,132 $\mathrm{IU} \mathrm{kg}^{-1} ; \mathrm{E}(\mathrm{min}) 60 \mathrm{IU} \mathrm{kg}^{-1} ; \mathrm{K} 3(\mathrm{~min}) 3.6$

$\mathrm{mg} \mathrm{kg}^{-1}$; B2 (min) $11 \mathrm{mg} \mathrm{kg}^{-1}$; B6 (min) $10 \mathrm{mg} \mathrm{kg}^{-1} ; \mathrm{B} 12$ (min) $40 \mathrm{mcg} \mathrm{kg}^{-1}$; calcium pantothenate (min) $36 \mathrm{mg} \mathrm{kg}^{-1}$; choline (min) $1,245 \mathrm{mg} \mathrm{kg}^{-1}$; niacin (min) $80 \mathrm{mg} \mathrm{kg}^{-1}$; folic acid (min) $5 \mathrm{mg} \mathrm{kg}^{-1}$; biotin (min) $10 \mathrm{mg} \mathrm{kg}^{-1}$; vitamin C (min) $29.4 \mathrm{mg} \mathrm{kg}^{-1}$; B1 (min) $4 \mathrm{mg} \mathrm{kg}^{-1}$. Minerals: sodium (min) $1,700 \mathrm{mg} \mathrm{kg}^{-1}$; organic selenium (min) $0.2 \mathrm{mg} \mathrm{kg}^{-1}$. Amino acids: methionine (min) 3,300 $\mathrm{mg} \mathrm{kg}^{-1}$; lysine (min) $10 \mathrm{~g} \mathrm{~kg}^{-1}$; threonine (min) 7,300 $\mathrm{mg} \mathrm{kg}^{-1}$; tryptophan (min) 2,400 $\mathrm{mg} \mathrm{kg}^{-1}$; glutamine (min) $14 \mathrm{~g} \mathrm{~kg}^{-1}$. Additives: BHT $22.7 \mathrm{mg} \mathrm{kg}^{-1}$. Fructooligosaccharides $2,000 \mathrm{mg} \mathrm{kg}^{-1}$. 
Horses were submitted to 7 physical examinations over the course of 12 hours. The following variables were monitored: heart rate, respiratory rate, mucous membrane colour, capillary refill time, rectal temperature, digital pulse and abdominal sounds (Speirs, 1999).

Data normality test were performed using the PROC UNIVARIATE and were analysed using the PROC GLM procedure of SAS statistical package for Windows (SAS Institute Inc., 2004). Buffering capacity and fecal $\mathrm{pH}$ data were evaluated using a mixed linear model. Mean values were compared using the Tukey test with a 5\% level of significance. Correlations between sample collection time and $\mathrm{pH}$, sample collection time and $\mathrm{BC} 6, \mathrm{BC} 6$ and $\mathrm{pH}$ and $\mathrm{BC} 5$ and $\mathrm{BC} 6$ were analysed using Pearson's correlation coefficient. Time-by-dose interaction effects and the isolated effect of time and increasing test product doses were investigated using the least significant difference (LSD) test.

\section{Results and Discussion}

Within 24 to 36 hours of test product administration, mean fecal pH was near 6 . Mean $\mathrm{pH}$ values did not differ significantly $(p=0.01)$ according to test product doses. However, in horses receiving the $75 \%$ or $100 \%$ doses, mean fecal $\mathrm{pH}$ values dropped below 6 at T24 and T36. Given horses were on a roughage-based diet, $\mathrm{pH}$ values measured before T24 were thought to reflect intestinal contents. This effect may persist beyond 24 hours. However, intestinal motility increased in response to test product feeding and T24 was consistent with changes in fecal $\mathrm{pH}$ and $\mathrm{BC} 6$ (Table 2).

Pre-gelatinized rice enriched with maltodextrin and inulin is the primary carbohydrate source in the product tested in this trial. The high digestibility of this type of carbohydrate has been demonstrated. De Marco, Peiretti, Miraglia and Bergero (2014) investigated the apparent digestibility of broken rice in equine diets and reported $89.5 \%$ and $92.6 \%$ digestibility of dry and organic matter respectively. Starch gelatinization is also thought to enhance product digestibility by rendering starch more susceptible to enzymatic attack (Vervuert, Coenen, \& Bothe, 2004). 


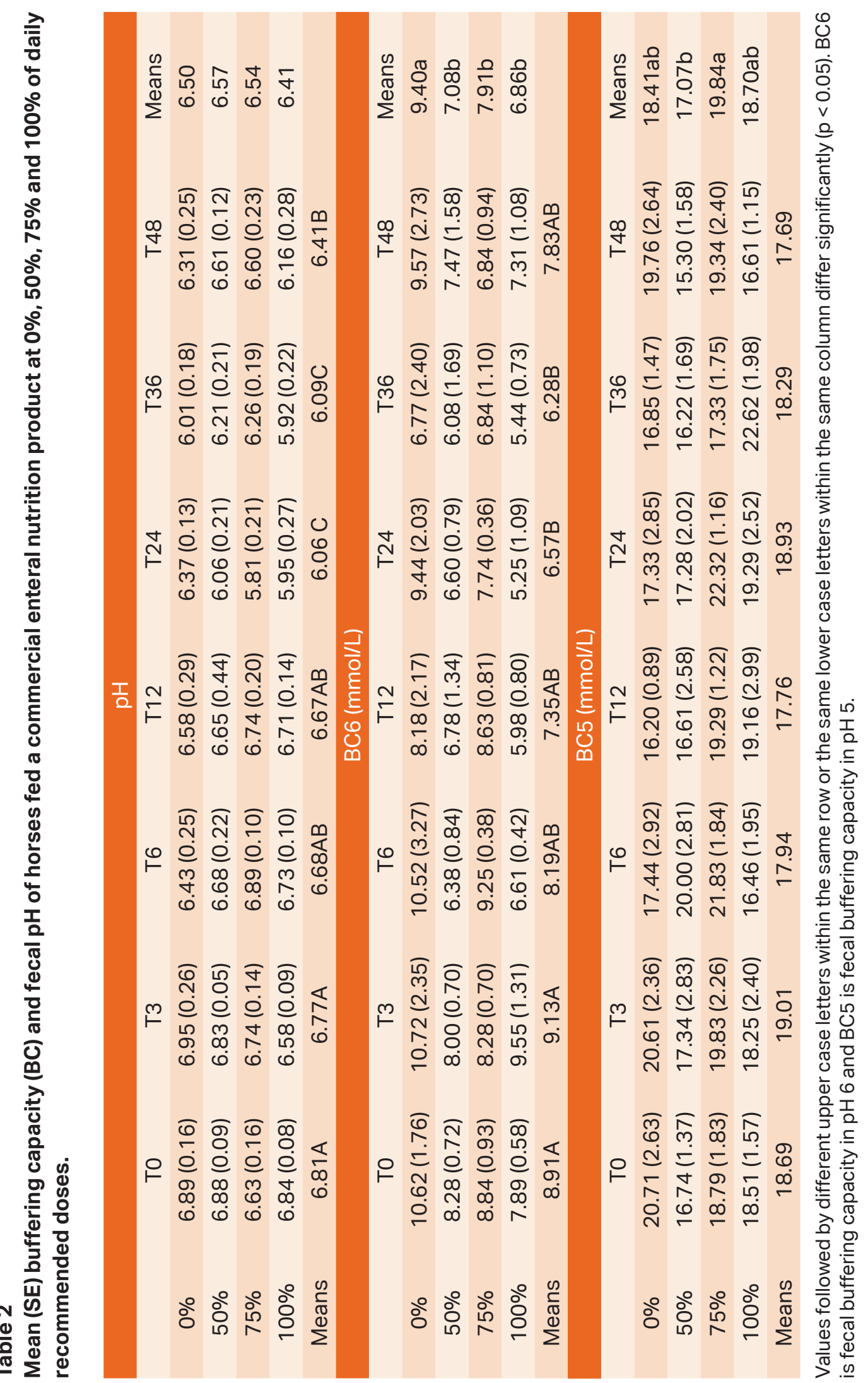


According to Julliand, De Fombelle and Varloud (2006), dietary levels of simple sugars and starches should not exceed $1 \mathrm{~g} \mathrm{~kg}^{-1}$ bwt $(0.1 \%$ bwt) per meal in horses. Excess starch is not fully absorbed by the small intestine in this species. Starch reaching the large intestine is used as substrate and may cause $\mathrm{pH}$ changes, affect the microbiota and increase the risk of diarrhea and laminitis development. The product tested in this study contains $475 \mathrm{~g}$ $\mathrm{kg}^{-1}$ of soluble carbohydrates (nitrogen-free extract). Horses in this sample weighed 300 $\mathrm{kg}$ on average. Product feeding at $1,000 \mathrm{~g}$ for $100 \mathrm{~kg}$ bwt (recommended dose) means horses fed the full dose (100\%) received 3 $\mathrm{kg}$ of enteral nutrition, or 1,425 $\mathrm{g}$ of soluble carbohydrates. Had horses been fed three smaller dose fractions, soluble carbohydrate intake would still have exceeded safe levels by $175 \mathrm{~g}$.

Low fecal $\mathrm{pH}$ has been demonstrated in horses fed diets with high hydrolysable carbohydrate content (Richards et al., 2006; Williamson et al., 2007; Berg et al., 2005) or submitted to dietary starch overload (Santos et al., 2009). Cecal acidosis may occur at a pH of 6. Osmotic diarrhea, preferential growth of gram positive bacteria and enhanced lysis of gram negative bacteria have been reported when large intestine $\mathrm{pH}$ drops below 6 (Van den Berg, Hoskin, Rogers, Grinberg, 2013).

In this study, $\mathrm{BC} 6$ and $\mathrm{pH}$ reached the lowest values at similar time points, suggesting horses may have developed unapparent acidosis due to their inability to fully buffer acids resulting from the fermentation of excess carbohydrates in the test product. However, the fact that horses retained buffering capacity at $\mathrm{pH} 5$ (BC5) suggests bicarbonate reserves were high enough to prevent $\mathrm{pH}$ from dropping to 5 . Therefore, horses did not develop clinical signs of acidosis and $\mathrm{BC} 5$ did not change significantly over the course of the experimental period.

Some horses fed the $75 \%$ or the full $(100 \%)$ dose passed soft feces on the day of product administration. However, these changes were short-lasting and feces regained normal consistency within 24 hours, suggesting transient acidosis development.

Optimal dilutionfortestproductdelivery via nasogastric tube was 3:1. Hence, horses fed the full (100\%) dose received 9 litres of water and $3 \mathrm{~kg}$ of product. Introduction of such a large volume of fluid into the stomach may have stimulated intestinal motility, resulting in temporary changes in stool consistency.

With the exception of water ( $0 \%$ dose), test product dose and sample collection time had a significant $(p=0.00)$ impact on BC6, with a more dramatic drop in pH at T24 and T36. In contrast, BC5 was significantly affected by product dose but not by sample collection time (Table 2).

Sample collection time was negatively correlated with $\mathrm{pH}(\mathrm{r}=-0.353, \mathrm{p}=0.0000)$ and BC6 $(r=-0.263, p=0.000)$, whereas BC5 and BC6 $(r=0.400, p=0.000)$ and $\mathrm{pH}$ and BC6 $(r$ $=0.538, p=0.000$ ) were positively correlated. These correlations support other findings of this study (Figure 1). 

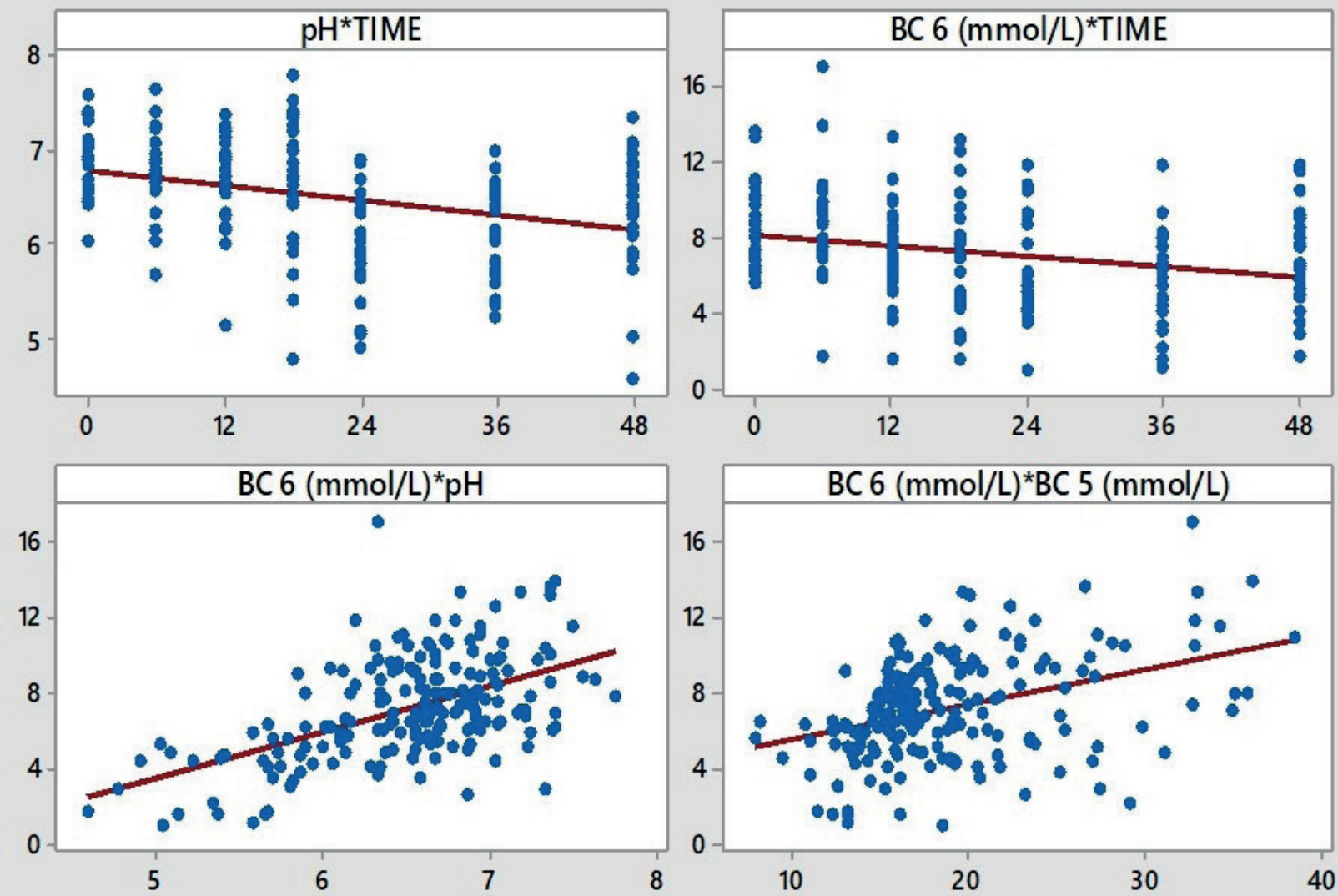

Figure 1. Correlations between sample collection time and $\mathrm{pH}$, sample collection time and $\mathrm{BC6}$, $\mathrm{BC} 6$ and $\mathrm{pH}$ and $\mathrm{BC} 5$ and BC6.

Physical examination revealed no abnormalities, except for increased intestinal motility in most horses within 3 to 6 hours of test product administration. Examination variables such as heart rate $(39 \pm 5$ beats per minute), respiratory rate (16 \pm 4 movements per minute) and rectal temperature (37.6 $\pm 0.5^{\circ} \mathrm{C}$ ) remained within normal ranges throughout the experimental period and no changes in digital pulse, mucous membrane colour or capillary refill time (1 to 2 seconds) were noted. Abdominal auscultation revealed intestinal gas build up in 9 out of 32 treatment times (28\%). Intestinal gas build up occurred in $37.5 \%$ (3 out of 8 ), $50 \%$ (4 out of 8 ) and $25 \%$
(2 out of 8) in horses fed the 50\%, 75\% and $100 \%$ dose respectively, but was not detected in any of the 8 treatments ( $0 \%$ dose). Intestinal motility was normal in $40 \%$, increased in $32 \%$ and decreased $28 \%$ of horses. Intestinal motility changes were more dramatic within 3 to 6 hours of test product administration, when $21 \%$ of horses developed hypermotility. This time frame is consistent with bolus digestion in the stomach and the small intestine (Weyenberg, Sales, \& Janssens, 2006). Hypermotility was less prevalent at T6 and T9 (6\%), but still more prevalent than prior to test product administration (T0,3\%). 
A final finding of this study was the observation of fat droplets in diluted fecal samples used for buffering capacity analysis. This was first noted at T3 and persisted throughout the experimental period in most horses and it appeared in greater proportion at higher doses. It was not an expected observation because this trial was conducted with healthy horses. Given the formula is indicated for animals suffering from digestive or metabolic conditions, total fat content may have exceeded experimental horses needs or small intestine digestion capacity.

\section{Conclusion}

The product had an impact on faecal $\mathrm{pH}$, buffering capacity and intestinal motility, therefore, it is recommended that the formulation be revised.

\section{Conflict of Interests}

None to declare.

\section{References}

Berg, E. L., Fu, J., Porter, J. H., \& Kerley, M. S. (2005). Fructooligosaccharide supplementation in the yearling horse: Effects on fecal $\mathrm{pH}$, microbial content, and volatile fatty acid concentrations. Journal of Animal Science, 83(7), 1549-1553. doi: $10.2527 / 2005.8371549 x$

Brøkner, C., Austbø, D., Naesset, J. A., Knudsen, K. E. B., \& Tauson, A. E. (2012). Equine pre-caecal and total tract digestibility of individual carbohydrate fractions and their effect on caecal pH response. Archives of Animal Nutrition, 66(6), 490-506. doi: 10.1080/1745039X.2012.740311

De Marco, M., Peiretti, P. G., Miraglia, N., \& Bergero, D. (2014). Apparent digestibility of broken rice in horses using in vivo and in vitro methods. Animal, 8(2), 245-249. doi: 10.1017/S175173111300205X

Geor, R. J. (2000). Nutritional support of the sick adult horse. Proceedings of KER Equine Nutrition Conference and Feed Manufacturers, Versalhes, Kentucky, USA.

Glunk, E. C., Pratt-Phillips, S. E., \& Siciliano, P. D. (2013). Effect of restricted pasture access on pasture dry matter intake rate, dietary energy intake and fecal $\mathrm{pH}$ in horses. Journal of Equine Veterinary Science, 33(6), 421-426. doi: 10.1016/j. jevs.2012.07.014

Hardy, J. (2003). Nutritional supportand nursing care of adult horse in intensive care. Clinical Techniques in Equine Practice, 2(2), 193-198. doi: 10.1053/\$1534-7516 (03)00015-5

Julliand, V., De Fombelle, A., \& Varloud, M. (2006). Starch digestion in horses: the impact of feed processing. Livestock Science, 100(1), 44-52. doi: 10.1016/j. livprodsci.2005.11.001

Julliand, V., \& Grimm, P. (2017). The impact of diet on the hind gut microbiome. Journal of Equine Veterinary Science, 52(May 2017), 23-28. doi: 10.1016/j.jevs.2017.03.002

Mechanick, J. I., \& Brett, E. M. (2002). Nutrition support of the chronically critically ill paciente. Critical Care Clinics, 18(3), 597-618. doi: 10.1016/s0749-0704(02) 00006-4 
Richards, N., Hinch, G., \& Rowe, J. (2006). The effect of current grain feeding practices on hindgut starch fermentation and acidosis in the Australian racing Thoroughbred. Australian Veterinary Journal, 84(11), 402-407. doi: 10.1111/j.1751-0813.20 06.00059.x

Santos, T. M., Almeida, F. Q., Godoi, F. N., Silva, V. P., França, A. B., Santiago, J. M., \& Santos, C. S. (2009). Capacidade tamponante, $\mathrm{pH}$ e consistência das fezes em equinos submetidos à sobrecarga dietética com amido. Ciência Rural, 39(6), 1782-1788. doi: 10.1590/S0103-8478 2009005000123

Speirs, V. C. (1999). Exame clínico em equinos. Porto Alegre: Ed. Artmed.

SAS Institute Inc. (2004). SAS statistical package for Windows (v. 9.1.3).

Stratton-Phelps, M. (2008). Equine diet supplements: rational use in clinical practice. Proceedings of Digestive Supplements Effects on Gut Health, ACVIM Forum, San Antonio, Texas, USA.

Van den Berg, M., Hoskin, S. O., Rogers, C. V., \& Grinberg, A. (2013). Fecal pH and microbial populations in Thoroughbred horses during transition from pasture to concentrate feeding. Journal of Equine Veterinary Science, 33(4), 215-222. doi: 10.1016/j.jevs.2012.06.004
Vervuert, I., Coenen, M., \& Bothe, C. (2004). Effects of corn processing on the glycaemic and insulinaemic responses in horses. Jounal of Animal Physiology and Animal Nutrition, 88(9), 348-355. doi: 10.1111/j.1439-0396.2004.00491.x

Weyenberg, V. S., Sales, J., \& Janssens, G. P. J. (2006). Passage rate of digesta through the equine gastrointestinal tract: a review. Livestock Science, 99(1), 3-12. doi: 10. 1016/j.livprodsci.2005.04.008

Williamson, A., Rogers, C. W., \& Firth, E. C. (2007). A survey of feeding, management and faecal $\mathrm{pH}$ of Thoroughbred racehorses in the North Island of New Zealand. New Zeland Veterinary Journal, 55(6), 337341. doi: 10.1080/00480169.2007.36790

Zeyner, A., Geibler, C., \& Dittrich, A. (2004). Effects of hay intake and feeding sequence on variables in faeces and faecal water (dry matter, pH value, organic acids, ammonia, buffering capacity) of horses. Journal of Animal Physiology and Animal Nutrition, 88(1), 7-19. doi: 10.1111/j.1439-0396.2004.00447.x 